\title{
Pendampingan Program Desa Makmur Peduli Api dalam Peningkatan Ekonomi Masyarakat dan Konservasi Hutan oleh Sinarmas Forestry di Region Jambi
}

\section{The Assistance of Desa Makmur Peduli Api Programin Increasing Community Economy and Forest Conservation by Sinarmas Forestry in Region Jambi}

\section{Canggih Rizki Nugroho, Sugihardjo, Hanifah Ihsaniyati}

Program Studi Penyuluhan dan Komunikasi Pertanian, Fakultas Pertanian

Universitas Sebelas Maret

J1.Ir.Sutami No.36 A Kentingan Surakarta 57126 Telp./Fax (0271) 637457

Email: canggihrizki277@gmail.com

\begin{abstract}
This study aims to find out about the assistance of the DMPA program in improving community economy and conservation of forest resources by Sinarmas Forestry in Jambi Region. Using a qualitative method with the EMIC approach described in a natural manner about the DMPA program in Jambi Region. The location of the study was conducted in Dataran Kempas Village (District I) and Sungai Rotan Village (District VIII) Jambi Province. The location was chosen based on data from PT Wirakarya Sakti that the two villages are villages with the recipients of the best DMPA program with two different assistance in the Jambi region. The study was conducted in April - June 2018 with snowballselected informants including SCD Manager Assistant, Dataran Kempas Village Head, District Secretary and Assistants of Dataran Kempas and Sungai Rotan Villages, DMPA program managers (chairman / member of farmer groups) and chairman of BUMDes Dataran Kempas. Data collection is done by interviews (independent interviews), observation, focus group discussions, and documentation. Data were analyzed using interactive analysis models. Based on the aspects studied, the results obtained were that the mentoring of the DMPA program in the study location villages had a positive influence on the community in raising awareness of forest conservation, but it still had no impact on improving the economy of the recipient community.
\end{abstract}

Keywords: Community Empowerment, CSRL DMPA, Sinarmas Forestry

Abstrak: Penelitian ini bertujuan untuk mengetahui tentang pendampingan program DMPA dalam peningkatan ekonomi masyarakat dan konservasi sumberdaya hutan oleh Sinarmas Forestry di Region Jambi.Menggunakan metode kualitatif dengan pendekatan emik yang dideskripsikan secara mandalam tentang program DMPA di Region Jambi. Lokasi penelitian dilakukan di Desa Dataran Kempas (Distrik I) dan Desa Sungai Rotan (Distrik VIII) Provinsi Jambi. Lokasi tersebut dipilih berdasarkan data PT Wirakarya Sakti bahwa kedua desa tersebut merupakan desa dengan penerima program DMPA terbaik dengan dua pendampingan yang berbeda di region Jambi. Penelitian dilakukan pada bulan April - Juni 2018 dengan informan yang dipilih secara snowball yang diantaranya adalah Asisten Manajer SCD, Kepala Desa Dataran Kempas, Sekdes dan Pendamping Desa Dataran Kempas dan Sungai Rotan, pengelola program DMPA (ketua/anggota kelompok tani) serta ketua BUMDes Dataran Kempas.Pengumpulan data dilakukan dengan wawancara (indepth interview), observasi, FGD, dan dokumentasi. Data dianalisis menggunakan model analisis interaktif.Berdasarkan aspek yang dikaji, diperoleh hasil bahwa pendampingan program DMPA di desa lokasi penelitian memberikan pengaruh yang positif kepada masyarakat dalam peningkatan kesadaran akan konservasi hutan, namun masih belum berdampak pada peningkatan ekonomi masyarakat penerima program.

Kata Kunci: CSR, DMPA, Pemberdayaan Masyarakat, Sinarmas Forestry 


\section{PENDAHULUAN}

Pemberdayaan dewasa ini tidaklah hanya menjadi tanggung jawab pemerintah saja, namun perusahaan swasta juga memiliki peran dalam memberdayakan masyarakat. Menurut Fuady (2013), perusahaan adalah suatu unit kegiatan yang melakukan aktivitas pengelolaan faktorfaktor produksi, untuk menyediakan barangbarang dan jasa bagi masyarakat, mendistribusikan serta melakukan upaya-upaya lain dengan tujuan memperoleh keuntungan dan memuaskan kebutuhan masyarakat.Peranan perusahaancukup vital dalam pembangunan bidang ekonomi suatu negara maupun masyarakat.Namun tidak dapat dipungkiri bahwa keberadaan perusahaan juga seringkali memunculkan berbagai permasalahan sosial dan lingkungan bagi masyarakat di sekitarnya, khususnya perusahaan yang bergerak dalam pengelolaan sumberdaya alam. Oleh karena itu, adanyamanejemen atas operasional perusahaan untuk menciptakan keselarasan dan keseimbangan menjadi penting. Manajemen atas keseimbangan operasional perusahaan dengan sosial dan lingkungan kemudian dituangkan dalam bentuk tanggung jawab sosial perusahaan.

Tanggung jawab sosial perusahaan atau yang lebih populer dengan istilah Corporate Social Responsibility (CSR) merupakan tindakan yang harusdiperhatikan oleh perusahaan dalam menjalankan setiap aktivitas bisnisnya. Tanggung jawab sosial berkaitan dengan tanggung jawab etis perusahaan terhadap dampak negatif lingkungan dan masyarakat (Hadi, 2011).Tanggung jawab sosial perusahaan ini merupakan upaya yang perlu dilakukan guna menyeimbangkan dan menyelaraskan kebutuhan hidup lingkungan dan masyarakat sekitar dengan dampak-dampak yang ditimbulkan oleh aktivitas perusahaan.

Salah satu sektor usaha yang aktivitasnya bersinggungan langsung dengan masyarakat dan lingkungan adalah perusahaan yang menjadikan hutan sebagai sumberdaya utama dari usahanya yang di sisi lain hutan Indonesia telah mengalami banyak kerusakan. Aktivitas mayarakat yang masih belum tahu maupun secara sengaja membuka lahan hutan menggunakan cara membakar tentu memberi dampak bagi masyarakat, perusahaan, dan bahkan pemerintah. Oleh karena itu, sudah menjadi tanggung jawab bersama bahwa konservasi lahan hutan haruslah dijaga, khususnya dalam hal mencegah kebakaran hutan dan perlindungan lahan yang bernilai konservasi tinggi di Indonesia. Maka pada tahun 2015 Sinarmas Forestry sebagai pemasok kayu Asia Pulp and Paper (APP) meluncurkan sebuah program pemberdayaan yang dikenal dengan Desa Makmur Peduli Api (DMPA).

Berada di tengah banyaknya konflik yang terjadi di lingkungan hutan antara perusahaan pengelola HTI dengan masyarakat lokal, ternyata DMPA mampu memberikan solusi dalam menciptakan hubungan yang harmonis antara perusahaan dengan masyarakat. Program DMPA bergerak dari upaya untuk mengurangi dampak kebakaran melalui intensifikasi lahan hutan.

Sebagai suatu program pemberdayaan masyarakat untuk desa diperlukan upaya untuk menciptakan program yang berkelanjutan di masyarakat maka dibutuhkan pendamping desa untuk memantau berjalannya program. Tujuanpendampingan desa menurut Permendesa RI Nomor 3 Tahun 2015 meliputi; (1) meningkatkan kapasitas, efektivitas dan akuntabilitas pemerintahan desa dan pembangunan desa, (2) meningkatkan prakarsa, kesadaran dan partisipasi masyarakat desa dalam pembangunan desa yang partisipatif, (3) meningkatkan sinergi program pembangunan desa antarsektor, dan(4) mengoptimalkan aset lokal desa secara emansipatoris.

Berdasarkan pemikiran tersebut, maka rumusan masalah penelitian ini adalah bagaimana pendampingan program DMPA dalam peningkatan ekonomi masyarakat dan konservasi hutan oleh Sinarmas Forestry di region Jambi?

\section{METODE PENELITIAN}

Penelitian ini menggunakan metode kualitatif dengan pendekatan emik yang diasumsikan oleh Foster (1978) bahwa pendekatan emik ini adalah pelaku atau aktor suatu tindakan itu lebih tahu tentang proses - proses yang terjadi dalam dirinya dari pada orang lain, kemudian pengetahuan mengenai proses mental ini diperlukan untuk memahami mengapa seseorang melakukan suatu tindakan atau mengapa seseorang menolak untuk melakukan tindakan tersebut. 




Gambar 1. Model Analisis Data Insteraktif

Lokasi penelitian di pilih secara sengaja yaitu Desa Dataran Kempas dan Desa Sungai Rotan sebagai desa yang memiliki perkembangan program terbaik menurut PT Wirakarya Sakti (WKS) dan memiliki tenaga pendamping yang berbeda. Penelitian ini menggunakan teknik penentuan informan secara snowballdengan teknik pengumpulan data melalui indepth interview, observasi, dokumentasi, dan FGD yang kemudian dianalisis menggunakan model analisis interaktif oleh Miles dan Hubermenyang dijelaskan oleh Sutopo (2006).

Jumlah informan dalam penelitian ini yaitu 26 orang yang terdiri dari Assistant Manager Social and Community Development PT WKS yang bertindak sebagai key informan dari perusahaan, Kepala Desa Dataran Kempas, Sekretaris Desa Dataran Kempas dan Sungai Rotan, Pendamping desa Dataran Kempas dan Sungai Rotan, Kelompok tani (ketua dan anggota) di kedua desa, Karang Taruna desa Dataran Kempas, dan Kepala BUMDes Dataran Kempas.

\section{HASIL DAN PEMBAHASAN}

Asia Pulp and Paper (APP) telah mendeklarasikan Forest Conservation Policy (FCP) pada tahun 2013 yang meliputi perlindungan terhadap High Conservation Value Forest (HCVF) dan High Carbon Stock (HCS), peatland management, social and community engagement dan responsible forest management di seluruh suppliernya. Sebagai supplierdari APP, Sinarmas Forestry menerapkan kebijakan FCP dengan mengimplementasikan program pemberdayaan masyarakat yaitu Desa Makmur Peduli Api (APP, 2017).

Program DMPA memiliki nama lain yaitu Intergrated Forestry and Farming System
(IFFS) dimana ruang lingkup dari DMPA adalah kehutanan dan pertanian terpadu. Program DMPA sendiri memiliki tujuan sebagai berikut; 1) Menghormati hak - hak masyarakat adat dan lokal atas wilayah sumberdaya hutan dan lahan, 2) Membangun relasi yang harmonis antara perusahaan, masyarakat dan para pihak lainnya, 3) Memperkuat dan memperluas dukungan pelaksanaan FCP, 4) Meningkatkan kesejahteraan dan ketahanan masyarakat desa, 5) Mencegah dan mengatasi terjadinya kerusakan hutan yang diakibatkan oleh pembakaran lahan / hutan, perambahan, pencurian kayu dan satwa, dan 6) Mencegah dan mengatasi konflik lahan. Target dari program DMPA yaitu melakukan pemberdayaan di 500 desa di 5 (lima) provinsi dan akan selesai dalam kurun waktu 2016-2020.

\section{Pendampingan Program Desa Makmur Peduli Api}

Program DMPA didukung dengan adanya pendampingan oleh fasilitator dalam pelaksanaan program di desa. Menurut Sumodiningrat (2009) perlunya pendampingan dilatarbelakangi oleh adanya kesenjanganpemahaman diantara pihak yang memberikan bantuan dengan sasaran penerimabantuan. Kesenjangan dapat disebabkan oleh berbagai perbedaan dan keterbatasankondisi sosial, budaya dan ekonomi.

Program DMPA yang oleh Sinarmas Forestry melalui PT Wirakarya Sakti diimplementasikan di region Jambi dengan menggunakan strategi yang telah disusun terlebih dahulu. Strategi implementasi program DMPA diantaranya adalah; 1) Penyiapan organisasi program, 2) Perencanaan dan pelaksanaan program, 3) Monitoring dan evaluasi. Pelaksanaan strategi program DMPA pun memiliki tahapan tahapan yang dilakukan.

Mengacu pada pelaksanaan tanggung jawab sosial perusahaan dalam pemberdayaan masyarakat, menurut Huraerah (2008) ada beberapa tahapan yaitu Assessment, Plant of treatment, dan Treatment action. Berdasarkan ketiga tahap tersebut, tahapan yang digunakan oleh Sinarmas Forestry dalam mengimplementasikan program DMPA pun menerapkan hal yang sama namun disesuaikan dengan kondisi lapangan dimana desa berada. Tahapan yang digunakan oleh perusahaan yaitu tahap persiapan, perencanaan, pelaksanaan dan diakhiri dengan monitoring. 
PT Wirakarya Sakti sebagai UMH yang berada di region Jambi dengan dibantu perusahaan partner memilliki 88 desa sasaran yang harus diselesaikan hingga tahun 2020 dan hingga bulan Juni 2018 telah ada 32 desa yang telah menerima program DMPA. Berdasarkan rekapitulasi realisasi program DMPA tahun 2016 - 2018 didapatkan desa - desa dengan pelakasanaan program DMPA yang dianggap paling berhasil. Hal tersebut juga didukung dengan pernyataan pihak Social and Community Development Head bahwa PT Wirakarya Sakti memiliki dua desa terbaik dengan pendampingan yang berbeda yaitu Desa Dataran Kempas di Distrik I dan Desa Sungai Rotan di Distrik VIII.

\section{Kegiatan Pendampingan Program Desa Makmur Peduli Api}

Kegiatan pendampingan desa program DMPA memiliki dua pilihan yaitu dengan PendampingDesaPerorangandanPendampingDesa Organisasi. Pendamping desa perorangan adalah pendamping desa yang ditunjuk oleh perusahaan setelah melalui seleksi dan diprioritaskan warga masyarakat desa calon penerima program itu sendiri. Sedangkan pendamping desa organisasi merupakan pendampingan desa yang dilakukan oleh organisasi mitra perusahaan seperti NGOs maupun LSM untuk melakukan tugas pendamping program DMPA.

Pendamping desa akan secara rutin (setiap bulan) dalam satu tahun periode untuk menyerahkan laporan kegiatan program DMPA yang berjalan di desa. Aktivitas masyarakat dalam melaksanakan program, kendala - kendala yang dihadapi, hingga konflik yang terjadi di masyarakat perlu dilaporkan secara tertulis kepada seksi Social and Community Development(SCD). Laporan tersebut kemudian menjadi evaluasi dan dasar pertimbangan bagi SCD dalam menentukan langkah berikutnya terkait program.

Desa Dataran Kempas memiliki program Budidaya Ikan Nila, program Budidaya Jahe Merah, program Ternak Domba, dan program Hortikultura. Sedangkan Desa Sungai Rotan memiliki program Ternak Itik Petelur, program Budidaya Ikan Nila Kolam, program Penambahan Bibit Ikan Lubuk Larangan, dan program Hortikultura. Masing - masing dari dua desa tersebut memiliki pendamping desa yang selalu membantu dalam pengelolaan program. Desa Dataran Kempas dibantu dengan pendamping desa dari warga desa sendiri, sedangkan Desa Sungai Rotan didampingi oleh LSM yaitu Yayasan Setara Jambi yang bermitra dengan PT Wirakarya Sakti.

Program DMPA dalam pelaksanaanya menggandeng Badan Usaha Milik Desa (BUMDes) sebagai mitra utama perusahaan. Lembaga BUMDes menjadi perwakilan desa untuk menjadi penggerak hibah sarana ekonomi yang diserahkan oleh perusahaan dalam implementasi program DMPA. Oleh karena itu, BUMDes turut menjadi salah satu pemegang kunci keberhasilan program DMPA yang juga akan dibantu oleh adanya pendamping desa.

Kegiatan Pendampingan yang diterima oleh kedua desa tersebut memiliki perbedaan. Perbedaan yang berasal dari tenaga pendamping yang tidak sama telah memberikan dampak yang berbeda juga terhadap pelaksanaan program DMPA di desa. Berikut peneliti sampaikan pendampingan di Desa Dataran Kempas dan Desa Sungai Rotan pada Tabel 1. 
Tabel 1. Pendampingan Program DMPA Desa Dataran Kempas dan Sungai Rotan

\begin{tabular}{|c|c|c|c|}
\hline No & Aspek & Desa Dataran Kempas & Desa Sungai Rotan \\
\hline 1 & Tenaga Pendamping & $\begin{array}{l}\text { Kader Pemberdayaan } \\
\text { Masyarakat Desa, Penduduk } \\
\text { desa yang direkomendasikan } \\
\text { pemerintah desa }\end{array}$ & $\begin{array}{l}\text { Pihak Ketiga, LSM yang } \\
\text { ditunjuk oleh Sinarmas } \\
\text { Forestry untuk bermitra }\end{array}$ \\
\hline 2 & $\begin{array}{l}\text { Jarak Psikologis } \\
\text { Pendamping Desa }\end{array}$ & $\begin{array}{l}\text { Dekat, mengenal sebatas } \\
\text { kepentingan program }\end{array}$ & $\begin{array}{l}\text { Dekat, mengenal sebagai } \\
\text { LSM yang memberdayakan } \\
\text { masyarakat sejak lama }\end{array}$ \\
\hline 3 & Waktu Pendampingan & $\begin{array}{l}\text { Tidak terbatas waktu, selalu } \\
\text { stand by untuk pengelola } \\
\text { program }\end{array}$ & $\begin{array}{l}\text { Waktu terbatas, tidak selalu } \\
\text { stand by di desa }\end{array}$ \\
\hline 4 & $\begin{array}{l}\text { Pelibatan PPL dalam } \\
\text { Program DMPA }\end{array}$ & $\begin{array}{l}\text { PPL aktif terlibat dalam } \\
\text { pengelolaan program DMPA }\end{array}$ & $\begin{array}{l}\text { PPL kurang bahkan tidak aktif } \\
\text { dalam pengelolaan program } \\
\text { DMPA }\end{array}$ \\
\hline 5 & $\begin{array}{l}\text { Pelibatan Pendamping } \\
\text { Desa dalam Kajian Desa }\end{array}$ & Tidak terlibat dalam kajian desa & Terlibat sejak awal kajian desa \\
\hline 6 & $\begin{array}{l}\text { Peningkatan } \\
\text { Perekonomian } \\
\text { Masyarakat }\end{array}$ & $\begin{array}{l}\text { Belum dirasakan karena belum } \\
\text { panen }\end{array}$ & $\begin{array}{l}\text { Sudah dirasakan, namun hanya } \\
\text { untuk segelintir penerima } \\
\text { manfaat saja }\end{array}$ \\
\hline 7 & Konservasi Hutan & $\begin{array}{l}\text { Masyarakat telah sadar akan } \\
\text { konservasi hutan, tidak ada } \\
\text { kebakaran dan perambahan hutan }\end{array}$ & $\begin{array}{l}\text { Masyarakat telah sadar akan } \\
\text { konservasi hutan, aktivitas } \\
\text { perambahan hutan berkurang }\end{array}$ \\
\hline
\end{tabular}

Sumber: Indepth Interview, observasi, dan FGD 2018

Pelaksanaan program DMPA di Desa

Dataran Kempas maupun di Desa Sungai Rotan Dataran Kempas Desa Sungai Rotan telah menerima banyak manfaat dari adanya program DMPA. Tujuan utama dari adanya DMPA yaitu perlindungan terhadap kebakaran hutan telah disadari masyarakat dengan semakin rendahnya aktivitas pembakaran hutan untuk membuka lahan. Upaya lain DMPA yaitu dalam peningkatan ekonomi masyarakat masih belum dirasakan masyarakat karena beberapa program belum panen atau dapat dirasakan hasilnya. Selain manfaat DMPA terhadap konservasi hutan yang terjaga dari kebakaran, manfaat lain yang diterima oleh masyarakat adalah terjalinnya hubungan yang harmonis antara perusahaan dengan masyarakat di sekitar hutan areal konsesi.

Pelaksanaan program DMPA tidak selalu berjalan lancar. Adapun beberapa kendala yang dihadapi oleh pendamping desa baik di Desa 
Tabel 2. Kendala Pendamping Desa

\begin{tabular}{lll}
\hline Kendala & Desa Dataran Kempas & Desa Sungai Rotan \\
\hline Pelatihan Program & $\begin{array}{l}\text { Tidak adanya pelatihan sebelum } \\
\text { program diturunkan, namun } \\
\text { masyarakat berinisiatif untuk mencari } \\
\text { pelatihan }\end{array}$ & $\begin{array}{l}\text { Tidak adanya pelatihan sebelum } \\
\text { program diturunkan }\end{array}$ \\
$\begin{array}{l}\text { Kesiapan } \\
\text { BUMDes }\end{array}$ & Aktif, Masih dalam taraf belajar & Kurang aktif, masih dalam taraf belajar \\
$\begin{array}{l}\text { Kompetensi } \\
\text { Pendamping Desa }\end{array}$ & $\begin{array}{l}\text { Berdasarkan kualifikasi pendamping } \\
\text { menurut Permendesa, kompetensi } \\
\text { pendamping desa masih belum } \\
\text { memadai }\end{array}$ & $\begin{array}{l}\text { Berdasarkan kualifikasi pendamping } \\
\text { menurut Permendesa, kompetensi } \\
\text { pendamping desa masih belum } \\
\text { memadai }\end{array}$ \\
\hline
\end{tabular}

Sumber: Wawancara dan Observasi 2018

Berdasarkan data yang diperoleh berupa potensi dan kendala yang dihadapi dalam implementasi program DMPA, peneliti mencoba untuk membuat matriks yang erat kaitanya dengan

Tabel 3. Matriks Pendamping Desa pendampingan program DMPA di Desa Dataran Kempas dan Desa Sungai Rotan yang dapat dilihat pada Tabel 3.

\begin{tabular}{|c|c|c|c|}
\hline DESA & KENDALA & REKOMENDASI & KEGIATAN \\
\hline \multirow{5}{*}{ Sungai Rotan } & Aspek Teknis & \multirow{4}{*}{$\begin{array}{l}\text { Peningkatan } \\
\text { Kapasitas SDM }\end{array}$} & \multirow{4}{*}{$\begin{array}{l}\text { Pelatihan dan Pelibatan } \\
\text { PPL dalam Program } \\
\text { DMPA }\end{array}$} \\
\hline & $\begin{array}{l}\text { Pelatihan Program yang } \\
\text { Kurang }\end{array}$ & & \\
\hline & $\begin{array}{l}\text { Rendahnya Partisipasi PPL } \\
\text { dalam Program }\end{array}$ & & \\
\hline & Aspek Non Teknis & & \\
\hline & $\begin{array}{l}\text { Minat Masyarakat terhadap } \\
\text { Budidaya Kurang }\end{array}$ & $\begin{array}{l}\text { Sosialisasi Tentang } \\
\text { Potensi Usaha } \\
\text { Budidaya }\end{array}$ & $\begin{array}{l}\text { Menunjuk kader } \\
\text { penggerak DMPA } \\
\text { yang juga pengurus di } \\
\text { BUMDes. }\end{array}$ \\
\hline \multirow{3}{*}{ Dataran Kempas } & Aspek Teknis & & \\
\hline & $\begin{array}{l}\text { Pelatihan Program yang } \\
\text { Kurang }\end{array}$ & \multirow{2}{*}{$\begin{array}{l}\text { Pemilihan } \\
\text { Pendamping } \\
\text { Desa yang sesuai } \\
\text { kompetensi }\end{array}$} & $\begin{array}{l}\text { Pelaksanaan Pelatihan } \\
\text { Sebelum Program Diberikan } \\
\text { pada Masyarakat }\end{array}$ \\
\hline & $\begin{array}{l}\text { Pemilihan Pendamping } \\
\text { Desa di Luar Kompetensi } \\
\text { Program }\end{array}$ & & $\begin{array}{l}\text { Seleksi Pemilihan } \\
\text { Pendamping Desa yang } \\
\text { Lebih Ketat }\end{array}$ \\
\hline
\end{tabular}

Sumber: Wawancara dan Observasi 2018

\section{KESIMPULAN DAN SARAN}

Hasil penelitian yang diperoleh dari lapangan dan pembahasan tentang pendampingan Program Desa Makmur Peduli Api di Provinsi Jambi yang dilakukan oleh PT Wirakarya Sakti, dapat ditarik kesimpulan bahwa pendampingan program DMPA di desa lokasi penelitian memberikan pengaruh yang positif kepada masyarakat dalam peningkatan kesadaran akan konservasi hutan, namun masih belum berdampak pada peningkatan ekonomi masyarakat penerima program.Masyarakat telah menerima manfaat 
DMPA dengan terjalinnya hubungan yang harmonis antara perusahaan dengan masyarakat sehingga dapat mengurangi kemungkinan terjadinya konflik.

Berdasarkan simpulan di atas, peneliti menyarankan bahwa perusahaan akan lebih bijaksana jika mulai memprioritaskan adanya pelatihan sebelum program diturunkan ke desa. Pelatihan ini diharapkan dapat meminimalisir kemungkinan kegagalan program yang disebabkan oleh pengetahuan dan keterampilan pengelola program yang rendah. Kemudian dibutuhkan kolaborasi antar desa penerima program DMPA supaya dapat menciptakan pasar komoditas sendiri sehingga tercipta jaminan pemasaran dan desa dapat saling memenuhi kebutuhan satu sama lain dan meningkatkan ekonomi masyarakat.

\section{DAFTAR PUSTAKA}

Asia Pulp and Paper. 2017. Desa Makmur Peduli Api. www.asiapulppaper.com. Diakses pada tanggal 10 September 2017

Foster, G. M. and Anderson. 1978. Medical Anthropology. Jhon Wiles \& Sons. New York

Fuady, M. 2013. Hukum Jaminan Utang. Erlangga. Jakarta.

Hadi, Nur. 2011. Corporate Social Responsibility edisi Pertama. Graha Ilmu. Yogyakarta.

Huraerah, Abu. 2008. Pengorganisasian dan Pengembangan Masyarakat. Humaniora. Bandung.

Peraturan Menteri Desa dan PDTT Nomor 3 Tahun 2015 tentang Pendampingan Desa

Sumodiningrat, Gunawan. 2009. Mewujudkan Kesejahteraan Bangsa Menanggulangi Kemiskinan dengan Prinsip Pemberdayaan Masyarakat. Alex Media Komputindo. Jakarta.

Sutopo, H. B. 2006. Metodologi Penelitian Kualitatif: Dasar Teori dan Terapannya dalam Penelitian. UNS Press. Surakarta. 